УДК $346.9(477)(045)$

\author{
Л. М. Ніколенко, Н. В. Іванюта
}

\title{
РОЛЬ ГОСПОДАРСЬКИХ ІНТЕРЕСІВ У ПРАВОВІЙ РЕГЛАМЕНТАЦІЇ ГОСПОДАРСЬКИХ ВІДНОСИН I ВИРІШЕННІ ГОСПОДАРСЬКИХ КОНФЛІКТІВ
}

Формування правової держави об'єктивно супроводжується активізаці$\epsilon ю$ пізнання головних пріоритетів європейської демократії, якими є права, свободи, інтереси та загальносошіальні цінності, їх охорона й захист. Для України, яка достатньо тривалий час перебуває у стані європейської інтеграції та модернізації правової системи, зазначений процес характеризується динамічною неоднорідністю й невизначеністю підходів до моделей запровадження дієвого захисту прав та інтересів. Зокрема, така тенденція зберігається і для системи захисту суб'єктів господарювання господарськими судами. При цьому на фоні оптимізації вдосконалення основних правових інструментаріїв усіх сегментів юридично значушої діяльності (законотворчої, правозастосовної тощо) у сфері судового захисту суб'єктів господарювання бажаного результату досягти не вдається. Причини недосягнення поставлених зав Јань $\epsilon$ різними, об'єктивними й суб'єктивними характеристиками. Однією з них, на нашу думку, $€$ надмірна концентрація правотворчих дій щодо прикладних аспектів у процесі еволюції концепцій прав і свобод відповідно до міжнародних стандартів здійснення правосуддя. Таке зосередження на вирішенні практичних завдань $є$ необхідним, але не єдиним шляхом досягнення оптимального стану певного сегмента регулювання. Адже вирішення теоретичних завдань не повинно залишатися поза увагою, поглиблюючи системну невідповідність законодавства, права й реальних суспільних потреб. В аспекті забезпечення якісного функціонування всієї господарської системи такими фундаментальними питаннями постають з'ясування ролі господарських інтересів, впливу на визначення пріоритетних напрямів, окреслення шляхів їх фактичного врахування під час формування та дій галузей господарського й господарського процесуального права.

Як доречно зазначав Д. Шепелєв, інтереси слугують важливим каналом формування законодавства, основою правозастосовної та правоохоронної 
роботи державних органів. Проблема інтересів сприяє сутнісному розумінню права, його ролі у відборі й визнанні найбільш значимих у соціальному стосунку інтересів, вираженні їх у законодавстві, установленні пріоритетів охорони та захисту окремих видів інтересів [1, с. 24-25].

Але необхідно враховувати, що й сама можливість реалізації певних інтересів залежить від поняття права, від об’єднання норм різних галузей права як елементів відповідної моделі, що взаємодіють [2].

Така складна взаємозалежність реалізації інтересів і певних галузей права зумовлює необхідність дослідження самих інтересів суб'єктів господарювання в контексті їх оцінювання та визначення форми взаємодії 3 основними системоутворювальними ознаками галузі господарського й господарського процесуального права.

Процес реформування сфери господарської діяльності та вирішення відповідних конфліктів повинен мати логіко-орієнтовний характер, базуватися на принципах відкритості й узгодженості запроваджених нововведень насамперед 3 інтересами самих суб์'єктів господарських відносин. Визначальним фактором цього твердження $\varepsilon$ загальновизнана роль стану збалансованості інтересів суб'єктів господарювання в динамічному розвитку національного господарства, диспропорційність яких украй негативно вПливає на рівень економіки самої держави.

Категорія «інтерес» виникла ше у XVIII в. Але, незважаючи на це, дискусійність і невизначеність у питання хї зумовленості в економічній науці не зменшується й на сьогодні. Також це питання не висвітлено достатньою мірою й у юридичних дослідженнях.

Першу спробу обгрунтування сутності поняття «інтерес»у уонтексті збільшення ефективності господарської діяльності було зроблено А. Тюрго. Інтерес як реальний, зумовлений відносинами власності, принципом економічної вигоди мотив і стимул соціальних дій шодо задоволення динамічних систем індивідуальних потреб визнатав і А. Генкін [3, с. 25]. Ю. Чуньков розглядав інтерес як зовнішню, відносно стійку форму вияву економічних відносин і законів, за якими вони розвиваються $[4$, с. 69$]$.

Зарубіжні вчені до проблеми економічних інтересів застосовують практичний, прикладний характер у сенсі використання економічних інтересів для досягнення конкретної мети [5, с. 87].

У більшості публікацій економічні та госпојарсыкі інтереси ототожнюються. Окремі автори сам господарський інтерес визначають як процес планування можливих результатів діяльності суб' $є$ кта господарювання $\mathrm{i}$ ï упорядкування відповідно до наявних потреб у ресурсах, які перебувають у його розпорядженні [6].

Сучасні дослідники визначають інтерес як ціннісну предметно-виборчу позицію особи, котра відображає усвідомлену нею потребу щодо необхідного й реально досяжного блага, на отримання якого спрямована об'єктивно зумовлена правомірна діяльність $[7$, с. 33-34].

Заслуговує на увагу твердження, шо в ринковій економіці саме зацікавленість у максимізації доходу $\epsilon$ необхідною й провідною силою всієї 
економічної діяльності [8, с. 3]. Тим самим господарські інтереси є водночас первинним джерелом, умовою та підставою виникнення господарських відносин.

У законодавстві часто застосовують поняття законного інтересу, чітке визначення якого відсутнє. Так, Конституція України визначає існування національних інтересів, інтересів національної безпеки, територіальної цілісності, політичних, економічних, соціальних, культурних інтересів, інтересів суспільства, інтересів громадянина, інтересів держави, спільних інтересів територіальних громад сіл, селищ і міст тошо.

У рішенні Конституційного Суду України від 01 грудня 2004 р. № 18рп/2004 [9] зазначається, що етимологічний зміст слова «інтерес» включає таке: а) увагу до кого-, чого-небудь, зацікавлення кимось, чимось; цікавість, захоплення; б) вагу; значення; в) те, шо найбільше цікавить кого-небудь, шо становить зміст чиїхось думок і турбот; г) прагнення, потреби; д) те, що йде на користь кому-, чому-небудь, відповідає чиїмось прагненням, потребам; вигоду, користь, зиск. У загальносоціологічному значенні категорія «інтерес» розуміється як об'єктивно існуюча й суб'єктивно усвідомлена соціальна потреба, як мотив, стимул, збудник, спонукання до дії; у психології - як ставлення особистості до предмета, як до чогось для неї шінного, такого, шо притягує. У юридичних актах термін «інтерес», ураховуючи його як етимологічне, так і загальносоціологічне, психологічне значення, уживається в широкому чи вузькому значенні як самостійний об'єкт правовідносин, реалізація якого задовольняється чи блокується нормативними засобами.

Крім того, у цьому рішенні зазначено, що, виходячи зі змісту ч. 1 ст. 8 Конституції України, охоронюваний законом інтерес перебуває під захистом не тільки закону, а й об'єктивного права загалом, шо панує в суспільстві, зокрема справедливості, оскільки інтерес у вузыкому розумінні зумовлюється загальним змістом такого права $\mathrm{i} \epsilon$ його складовою. «Одним з проявів верховенства права, - підкреслюється у підпункті 4.1 Рішення Конституційного Суду Украіни у справі про призначення судом більш м'якого покарання від 02 листопада 2004 року № 15 -рп/2004, - $\epsilon$ те, що право не обмежується лише законодавством як однією з його форм, а включає й інші соціальні регулятори, зокрема норми моралі, традиції, звичаї тошо, які легітимовані суспільством і зумовлені історично досягнутим культурним рівнем суспільства. Всі ці елементи права об'єднуються якістю, шо відповідає ідеології справедливості, ідеї права, яка значною мірою дістала відображення в Конституції України».

Отже, відповідно до ідеї справедливості, самі інтереси суб'єктів повинні природно формуватися й утілюватися в юридичній свідомості. Але сьогодення характеризується існуванням парадигмальних позицій щодо характеристики фундаментальних орієнтирів самої справедливості як філософської, теологічної, правової, моральної категорії. Так, С. Алексєєв зазначає, шо справедливість набуває значення правового принципу тією мірою, якою вона втілюється в нормативно-правовому способі регулювання, 
у тих засадах пропорційності, рівності тошо, які властиві самій побудові правової доктрини $[10$, с. 65]. На особливу увагу заслуговує рішення Конституційного Суду України від 02 листопада 2004 року № 15-рп/2004, де зазначено, шо справедливість - одна з основних засад права, $€$ вирішальною у визначенні його як регулятора суспільних відносин, одним із загальнолюдських вимірів права. Елементи права, зокрема розмірність, рівність, мораль, об'єднуються якістю, що відповідає ідеології справедливості, ідеї права, яка значною мірою дістала відображення в Конституції України [11]. Таке розуміння справедливості дає підстави застосування іiі як правової категорії із властивостями прямої діiі, зокрема, у судовій практиці.

Вишезазначені підходи до розуміння поняття інтересу демонструє складний, різновекторний характер цієї категоріі.

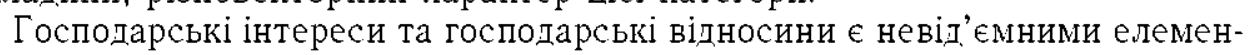
тами господарської системи, у межках якої розвивається економіка. У сфері господарювання держава здійснює довгострокову (стратегічну) й поточну (тактичну) економічну та соціальну політику, спрямовану на реалізацію й оптимальне узгодження інтересів суб'єктів господарювання і споживачів, різних суспільних верств і населення загалом [12].

Самі ж господарські відносини являють собою діяльності суб'єктів господарювання у сфері суспільного виробништва, яка спрямована на виготовлення та реалізацію продукції, надання послуг, виконання робіт вартісного характеру, шо мають цінову визначеність [12]. Фундаментальні праці щодо виокремлення характеристик зазначених відносин були здійснені В. Мамутовим [13, с. 81-94], I. Побірченко, Г. Знаменським.

$\mathrm{V}$ господарських правовідносинах реалізуються як приватні, так і публічні інтереси. Природа інтересів, які реалізуються у правовідносинах, передусім зумовлена сферою фактичних відносин, шо зазнали регулювального впливу права $[14$, с. 16-17]. Можна погојитись із думкою В. Мілаша, шо сучасна система економічних потреб, за јопомогою яких формуються економічні інтереси, в узагальненому вигляді склалається з такого: 1) із структуроутворювальних потреб в економічній безпеці, безперервності суспільного відтворення та виробництва товарної маси, у залученні інвестицій до найбільш важливих сфер суспі.льного виробництва, формуванні дохідної частини бюджетів (запобіганні створенню дефіциту бюджету), запобіганні загрозі дефіциту товарів, підтриманні конкурентного середовища, забезпеченні продовольчої безпеки, безпеки здоров'я людини й довкілля (екологічна безпека), у підтриманні й захисті економічної конкуренції та вітчизняних товаровиробників, у реструктуризації та інноватизації вироб́ництва тошо; 2) із потреб́ активних суб́'єктів економічної діяльності у здобутті економічних вигод у формі підприємницького прибутку й пов'язаних із ними виробничих потреб, зокрема в самоінвестуванні власного виробництва (товарів, робіт, послуг) шляхом залучення різноманітних виробничих ресурсів; до цієї групи автор також включає інвесторів; 3) платоспроможних потреб споживачів у результатах господарської діяльності (споживчі потреби). 
При цьому цільова реалізація таких інтересів і динамічність відповідних відносин можлива тільки за оптимального функціонування суб' $є к т і в ~$ господарювання. Тому сама сфера господарювання потребує різновекторного забезпечення з боку держави (політичного, соціального тошо). Але динамічна роль у цьому контексті належить саме належному правовому забезпеченню. Така роль права зумовлюється необхідністю здійснення інтеграції наявних інтересів у правове поле задля окреслення меж їхньої реалізації, способів захисту; стимулювання формування нових інтересів; демонстрації об’єктивного врахування потреб суспільства.

Варто зазначити, шо більшість розвинених держав, у результаті швидкого розвитку господарських (комерційних) зв'язків та усвідомлення об' $є$ ктивної важливості іх регламентації в правовій системі, запровадили шодо відповідних відносин спеціальне юридичне оформлення (з урахуванням своїх національних особливостей у шій сфері).

Так, у Німеччині ще в 1861 р. був прийнятий Німецький торговий кодекс, який навіть після прийняття Цивільного кодексу не втратив (а навіть навпаки) свого значення. Комерційні кодекси діють в Австрії, Аргентині, Бельгії, Болгарії, Греції, Єгипті, Іспанії, Кореї (Південній), Кувейті, Люксембурзі, Мексиці, Польші, Румуніі, Словаччині, Франції, Чехіі, Чилі, Швешіі, Естоніі, Японії тошо. Крім того, тенденція розвитку комерційного (господарського) законодавства спостерігається й на сьогодні (наприклад, в Іспаніі).

Україна в питаннях розвитку правової регламентації відповідних господарських відносин досягла значних результатів. Зокрема, здійснена кодифікація господарського законодавства в Господарському кодексі України 2003 р., який став прикладом сприйняття європейських традицій роздільної кодифікації цивільного та господарського (торгового, комерційного) законодавства.

Крім того, в Україні закріплено дієву правову основу вирішення господарських «конфліктів» (зокрема йдеться про Господарський процесуальний кодекс України).

Справді, стрімкість розвитку господарських відносин, зміна господарського права породжує різноплановість численних господарських спорів та інших правових питань. Господарське процесуальне право (далі - ГПП) як регулятор сфери захисту прав у випадку їх порушення чи оспорювання має збалансовано реагувати й відповідати новим обставинам. Також роль ГПП збільшується в умовах поширення гуманістичного праворозуміння права та переосмислення молелі правосуддя через призму міжнародного постулату справедливості, які закладені насамперед у Конвенції про захист прав людини і основоположних свобод.

Розуміння та своєрідність взаємовідносин інтересу з процесуальними галузями права визначено в позиції $M$. Гурвича, який стверджував, що, на відміну від матеріального суб'сктивного права, охоронюваний законом інтерес (законний інтерес) є «вигода, забезпечена не нормою матеріальною, а охоронною, насамперед, процесуальною нормою» $[15$, с. 86]. Д. Левченко 
також відзначав суттєву роль інституцій захисту певних інтересів. Так, він стверджував, шо зміст законного інтересу склалається із двох елементів (прагнень): користуватися конкретним соціальним благом і звертатися в необхідних випадках за захистом до компетентних органів держави або громадських організашій [16].

Дійсно, соціальна роль ГПП виявляється в такому:

- вирішенні конфліктів у сфері господарських та інших правовідносин;

- забезпеченні справедливого судового захисту порушених або оспорюваних прав та інтересів;

- відповідності й достатності правого регулювання в кожному випадку.

Виконання такої ролі ГПП забезпечує, так би мовити, «повний цикл» врахування та забезпеченості господарських інтересів.

Крім того, ураховуючи роль суду в реалізації захисту прав і свобод. людини, громадянина, суб' $є$ ктів господарювання й забезпечення контролю за діяльністю органів державної влади, можна констатувати наявність нерозривного зв'язку понять «справедливість» (яка, за позицією Конституційного Суду України, робить можливим перебування охоронюваного інтересу під захистом не тільки закону) $\mathrm{i}$ «правосуддя». Справді, процеси реалізації й забезпечення прав та інтересів осіб через призму справедливості неможливо розглядати без сфери правосуддя, яка вияв.ляється, зокрема, і у формі господарського судочинства.

Ураховуючи, шо саме інтереси, які визначаються умовами господарювання, що постійно змінюються, на кожному новому етапі розвитку підприємств і характеризуються особливостями конкретного періоду ї діяльності, формують основні пріоритети й, відповідно, цілі та завдання розвитку того чи іншого суб'єкта господарювання [17], можливо дійти таких висновків.

По-перше, важливим показником демократичного устрою суспільства на певному етапі розвитку $є$ обов'язковість вираження інтересів у праві як головної системоутворювальної категоріі, до того ж як у матеріальному, так і процесуальному праві. Певні інтереси як первинно значущі категорії можуть отримати свою реалізацію, охорону й захист виключно в межах, установлених правом.

По-друге, динаміка змісту інтересів обов'язково повинна позначатися на змісті правового регулювання як для забезпечення нормального ринкового режиму господарського обігу, так і для вирішення конфліктних явищ. При шьому, думається, шо сприйнятливим сегментом певної галузі права на зміну інтересів $\in$ функції права.

Таке твердження грунтується на тому, шо функціям права притаманна пряма залежність від суспільних відносин (зокрема й інтересів, які спонукають до їхнього виникнення, трансформації тощо). Сама ж функція права в ії класичному розумінні являє собою єдність двох моментів: а) ролі (призначення) права в суспільстві; б) основних напрямів його впливу на суспільні відносини $[18$, с. 150]. Саме ж формування пріоритетних напрямів впливу об'єктивно неможливо подати без урахування й оцінювання ін- 
тересів. Отже, у взаємовідносинах права (як сукупності норм) та інтересу останній у цих зв'язках є первинним.

По-третє, трансформашійність інтересів зумовлює періодичне певне перетворення системи правового регулювання. Але ці перетворення, зокрема в сфері господарювання, не повинні мати характер «шокової терапї» 3 якостями монополізаційних тенденцій і відриватися від сучасних потреб, особливо в період глибокої кризи й браку коштів у держави.

Саме ж деформування правової регламентації та змісту самих господарських відносин без урахування реальних господарських інтересів може призвести до такого:

- зниження мотиваційності інтересу до високоякісної господарської діяльності у зв'язку з відсутністю гарантій імовірності ї реалізашіі;

- зростання тінізації здійснення відповідної діяльності;

- посилення недобросовісних і рейдерських явиш;

- спад інвестиційної привабливості тощо.

Системна і структурна неузгодженість інтересів суттєво зменшує перспективи зростання економічного рівня в державі. Сподівання щодо ефективності дії економічних законів в Україні апріорі не можуть перетворитися на фактичну дійсність без належного оцінювання, а в деяких випадках і прямого нехтування господарськими інтересами.

У шьому аспекті викликає певні побоювання актуалізашія ідей скасування не тільки Господарського кодексу Украӥни, а й Господарського процесуального кодексу України. Так, останні ініціативи в цьому контексті були представлені Державною судовою адміністрацією наприкінці серпня 2014 р. в межах законопроекту «Про внесення змін до Закону України «Про судоустрій і статус судів» та інших законодавчих актів шодо удосконалення засад організації та функціонування судової влади відповідно до європейських стандартів», який, зокрема, у Перехідних положеннях передбачав втрату чинності Господарського кодексу України. Ця інішіатива не була законодавчо втілена, ії противагою стало прийняття Закону України «Про забезпечення права на справедливий суд» від 12.02 .2015 p. № 192-VIII. Однак і після цього спроби, як зазначає О. Подцерковний, знівелювати особливості господарського судочинства не припиняються. Прикладом цього є проект Закону від 16.03.2015 р. № 2382 про внесення змін до деяких законодавчих актів України (шодо окремих правових аспектів поліпшення позицій України в рейтингу Doing Business).

Отже, питання запровадження моделей і механізмів подолання диспропорцій незахишених господарських інтересів $€$ нагальними для сучасних правових реалій.

\section{Література}

1. Шепелев Д.В. Проблемы реализации и защиты интересов в праве : автореф. дисс. ... канд. юрид. наук : спец. 12.00 .01 «Теория и история права и государства; история учений о праве и государстве» / Д. В. Шепелев. - М., 2011. - 25 с. - ЮЭлектронный ресурс]. - Режим доступа: http: / / law.edu.ru/book/book.asp?bookID=1433732. 
2. Киреева Е.А. Общетеоретические проблемы построения, фуніццинирования и взаимодействия моделей правореализационного поведения / Е.А. Киреева ҐЭлектронный реcурсl. - Режим доступа : http://dspace.susu.ac.ru/bitstream/handle/0001.74/1418/13. pdf? sequence $=1$.

3. Генкин А. Система экономических интересов и социальная гармония / А. Генкин // Вопросы экономики. - 1993. - № 6. - С. 2.

4. Чуньков Ю.И. Взаимодействие об́ъективного и субъективного в социалистической экономике / Ю.И. Чуньков. - Томск : Изд-во ТГУ, 1984. - 194 с.

5. Экономическая теория: Краткий курс:|учебник|/ |В.Д. Камаев, М.З. Ильчников, Т.А. Борисовская]. - 2-е изд. - М. : КНОРУС, 2007. - 384 с.

6. Бияков О.А. Региональные экономические интересы и проблемы измерения их согласованности / О.А. Бияков, Н.Ю. Коломарова ЮЭлектронный ресурсl. - Режим доступа : http://vtit.kuzstu.ru/books/shell/book5/doc/chapterl.html.

7. Даньков А.А. Обеспечение баланса пуб.личных н частных ннтересов в сфере правосудня: автореф. дисс. ... канд. юрид. наук : спец. 12.00 .01 «Теория и история права и государства; история учений о праве и государстве» / А.А. Даньков. - М., 2014. - 34 с. - Электронный pecypcl. - Режим доступа : http://www.dslib.net/teoria-prava/obespechenie-balansapublichnyh-i-chastnyh-interesov-v-siere-pravosudija.html.

8. Плотницкий И.М. Курс экономнческой теорни / И.М. Плотницкнй. - Мн. : ИнтерпрессерBис, 2003. - $496 \mathrm{c}$.

9. Щодо офіційного тлумачення окремих положень частини першої статті 4 Цивільного процесуального кодексу України (справа про охоронюваний законом інтерес) : Рішення Конституційного Суду У Країни від 1 грудня 2004 року № 18pп/2004 [Електронний ресурс]. - Режим доступу: http://search.ligazakon.ua/__doc2.nsi/link1/KS04025.html.

10. Aлексеев С.С. Теорня права : в 2 т. / С.С. Алексеев. - М. : Крнд. лнт., 1982. - 360 с.

11. Щодо відповідності Конституції України (конституційності) положень статті 69 Кримінального кодексу України (справа про призначення судом більш м'якого покарання) : Рішення Конституціӥного Суду України від 01 листопада 2004 р. № 15-рп/2004// Урядовий kур'єр. - 2004. - № 219.

12. Господарський кодекс України : Закон України від 16.01.2003 p. JNo 436.IV // Відомості Верховної Ради України. - 2003. - № 18. - Ст. 144.

13. Хозяйственное право : Гучебник] / под ред. В.К. Мамутова. - К. : Юринком Интер. 2002. C. $81-94$.

14. Мілаш В.С. Господарське право: |курс лекцій| : у 2 4. / В.С. Мілаш. - Х. : Право, 2008. Ч. 1. - 2008. - 496 c.

15. Гурвич М.А. Гражданские процессуальные правоотношения и процессуальные действия / М.А. Гурвич // Труды ВКЗИ. Вопросы гражданского процессуального, гражданского и трудового права. - М., 1965. - С. 86.

16. Левченко В. До визначення поняття законний інтерес / В. Левченко / / Актуальні проблеми державн і права |Електронний ресурсl. - Режнм доступу: http://apdp.in.ua/v36/34.pdí.

17. Стратегический потенциал и формирование приоритетов в развитии предприятий : |монография] / [И.Р. Бузько, И.Е. Дмитренко, Е.А. Сушенко]. - Алтевск : Изд-во ДГМИ, 2002. 216 c. - ГЭлектронный ресурс]. - Режим доступа: http://book.net/index.php?p=chapter\& bid $=381$ \& chapter $=1$.

18. Лнвшнц Р.3. Теорня права / Р.3. Лнвшиц. - М. : БЕК, 2001. - 224 с.

\section{A н о т а ц і я}

Hiкалекко Л. М., Іеакюma H. В. Роль господарських інтересів у правовій регламентації господарських відносин і вирішенні господарських конфліктів. - Стаття.

У статті проведено теоретичне дослідження поняття гослодарського інтересу в аспекті правового забезпечення якісного функціонування господарської системи, його впливу на позначення пріоритетних напрямів, визначення характеру співвідносності з галузями права.

Kлнtовi choвa: господарський інтерес, господарські відносини, функція, господарське судонинство, справедливість. 


\section{Анн о т а ция}

Николенко Л. Н., Иванюпа Н. В. Роль хозяйственных интересов в правовой регламентации хозяйственных отношений и разрешении хозяйственных конфликтов. Статья.

В статье проведено теоретическое исследование понятия хозяйственного интереса в аспекте правового обеспечения качественного функционирования хозяйственной системы, его влияния на обозначение приоритетных направлений, определение характера соотношения с отраслями права.

Kantleвые слова: хозяйственный интерес, хозяйственные отношения, функция, хозяйственное судопроизводство, справедливость.

\section{Su m m a r y}

Nikolenko $L$. N., Joanyuta $N$. $V$. The role of economic interests in the legal regulation of economic relations and the resolution of economic conflicts. - Article.

In this article a theoretical study of the concept of economic interest in the aspect of legal support the proper functioning of the economic system and its impact on the designation of priority areas, the definition of the nature of the relations with the branches of the law.

Key words: economic interest, economic relations, function, Commercial Litigation, equity. 